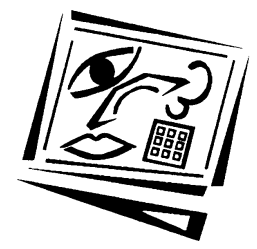

\title{
Pedagogical approaches for ICT integration into primary school English and mathematics: A Singapore case study
}

\author{
Lee Yong Tay, Siew Khiaw Lim \\ Beacon Primary School, Singapore \\ Cher Ping Lim \\ Hong Kong Institute of Education \\ Joyce Hwee Ling Koh \\ Nanyang Technological University
}

\begin{abstract}
This case study research attempts to examine the pedagogical approaches for the teaching of English and mathematics with information communication technology (ICT) in a primary school in Singapore. The study uses the learning with and learning from ICT framework in reporting and analysing how ICT has been used in the teaching of English and mathematics. This framework also looks into the level of production (i.e., students' creation of digital work) and collaboration when learning with and/or from ICT. From the review of documents and lesson plans; interviews with teachers; group interviews with students; and questionnaire survey of the students on their frequency of ICT use, the findings seem to suggest a difference in the pedagogical approach adopted by English and mathematics teachers. The frequency of ICT use was also reported to be significantly higher in English lessons compared with mathematics lessons. Mathematics teachers primarily adopted the learning from ICT pedagogy with occasional learning with ICT approach. However, English teachers facilitated the students to learn from and also with technology, with production and also with elements of collaboration. This case study illuminates the usefulness of the learning with and from ICT as a conceptual framework in guiding both researchers and teachers to be more aware of the pedagogical implications when ICT is added in the teaching and learning process. This case study also once again suggests the pivotal role of the teacher.
\end{abstract}

\section{Introduction}

The main intent of this case study is to obtain a more in depth understanding of how ICT has been integrated into the teaching of English and mathematics in a primary school from the learning from and learning with ICT framework (Ringstaff \& Kelley, 2002) that looks into students' level and extent of production and collaboration (Bower, Hedberg \& Kuswara, 2010). Of the various learning subjects offered in the primary schools in Singapore, English language and mathematics are very important academic subjects that take up a significant portion of the students' time in school. Half of the total curriculum time is devoted to these two subjects and students have English and mathematics lessons every day. The nature of the two subjects is different - the learning of English focuses on the expression of one's ideas and thoughts through the use of text and multimedia, to develop not only language skills but also media literacy, whereas the learning of mathematics focuses on acquisition of problem-solving skills 
and concepts. Hence, due to the differences in terms of the content of the two subjects, the pedagogical approaches could be different and this may in turn influence how ICT could be used in the teaching of these subjects.

The main objective of this paper is to explore how ICT has been integrated into the teaching of English and mathematics in a primary school. The paper also investigates whether there is a difference in terms of pedagogical approach adopted by the teachers in using ICT for the teaching of English and mathematics.

\section{Background of study}

The school in this case study research is the first primary future school that was set up under the FutureSchools@Singapore program in 2008. The school's core mission is to seek innovative teaching approaches that leverage on technologies to better engage the new generation of young learners. The school has implemented a successful one-to-one program (i.e., one-to-one computer to student ratio) for all its students. The program ensures a two-to-one student to computer ratio for its Primary 1 students and one-toone student to computer ratio for Primary 2 and 3. Computer ownership program, where students procure and own their own notebook computers, has been introduced to all Primary 4 students. The program promotes the vision for every child to own a personal learning device to support, extend and enrich their learning. A studentowned model is adopted to ensure sustainability of the one-to-one program.

\section{Theoretical framework}

\section{Learning from and with ICT}

Broadly speaking, learning from and learning with ICT could provide a very useful conceptual framework when integrating ICT into teaching and learning. Learning from the computer inclines towards the behaviouristic theories of learning whereas learning with ICT has its roots in the constructivist and social constructivism paradigms. More passive behaviours such as reading and listening are associated with learning from ICT, while more active behaviours such as creating, writing and updating are associated with learning with ICT (Harris \& Rea, 2009).

Learning from computers takes various forms - computer-based instruction, computerassisted instruction and intelligent learning system, to name a few. Basically, learning from computers sees the computer system as a tutor. Despite earlier cautionary findings, research studies provide considerable evidence on how to make the most of using computers as tutors. "In recent years, a number of studies have provided convincing evidence that such technology can be effective in teaching basic skills" (Ringstaff \& Kelley, 2002, p. 3). "However, it would be short-sighted to focus only on how best to have students learn "from" computers - that is, using technology to tutor students on basic skills. Technology has advanced beyond this tutorial function and can do so much more than what is readily measured by standardised tests" (Ringstaff \& Kelley, 2002, p. 5).

While learning from computers can help students to enhance their performance on basic skills, learning with computers could facilitate the learning of higher-order thinking (Jonassen, 2000; Lim \& Tay, 2003). Higher order thinking is more than the simple recall of facts or information retrieval. It is a function of interaction between 
cognitive strategies, meta-cognition and non-strategic (domain-specific) knowledge during novel problem solving (Young, 1997). "Many researchers investigating the use of technology in education have found that technology is most powerful when used as a tool for problem solving, conceptual development and critical thinking" (Ringstaff \& Kelley, 2002, p 5). However, as compared to the learning of basic knowledge and skills, it is much harder to quantify the learning of higher order type of thinking and skills.

\section{Production and collaboration with ICT}

Bower, Hedberg and Kuswara (2010) further propose a framework for technology learning design, suggesting four types of online pedagogies - transmissive, dialogic, constructionist and co-constructive. These pedagogies are categorised according to their degree of production and collaboration. The transmissive pedagogical approach, where the basic paradigm is learning from ICT, is based on information delivery approaches with information broadcast and made available to learners. For dialogic, constructionist and co-constructive pedagogies, they provide opportunities for interaction and construction that allow students to learn with ICT.

There are merits to each of the learning pedagogies, depending on the different stages of the learning cycle. Direct instructional or the transmissive approaches would be more appropriate for beginners who have yet to form understanding about a particular topic. The dialogic pedagogical approaches allow learners to extend their learning and understanding beyond what they could achieve in isolation. Extended learning takes place through discussions and dialogues with peers and instructors. The constructionist pedagogy assumes that students learn by reconstructing their knowledge. This approach often encourages students to use open tools to create and produce what they have learned. The co-constructive approaches place emphasis on the power of groups and teamwork, where students work with their peers to coconstruct knowledge. Table 1 provides a matrix of pedagogies according to the degree of production and collaboration.

Table 1: Pedagogies categorised according to the degree of production and collaboration - learning from and learning with technology (adapted from Bower, Hedberg \& Kuswara, 2010; Ringstaff \& Kelley, 2002)

\begin{tabular}{|c|c|c|}
\hline & No collaboration & Collaboration \\
\hline No product & $\begin{array}{c}\text { Transmissive } \\
\text { (learning from technology) }\end{array}$ & $\begin{array}{c}\text { Dialogic } \\
\text { (learning with technology) }\end{array}$ \\
\hline Product & $\begin{array}{c}\text { Constructionist } \\
\text { (learning with technology) }\end{array}$ & $\begin{array}{c}\text { Co-constructionist } \\
\text { (learning with technology) }\end{array}$ \\
\hline
\end{tabular}

\section{Use of ICT in the teaching of English}

Abas, Fong, Yu and Lee (2010) and Tay, Nair and Lim (2010) described how a digital story telling approach was used in a primary school. Tablet computers (a variant of notebook computers) were used by young learners (aged 7 to 8 ) to create digital stories with text, digital images, simple animations and their own voices with commonly and easily available presentation software applications. It was reported that the engagement and motivation were noticeably high, and non-ICT activities such as scaffolding by teachers were as important as the ICT activities in engaging the pupils and the progress of the lessons. 
Andrews, Freeman, Hou, McGuinn, Robinson and Zhu (2007) reviewed more than 2000 papers published between the year 1998 to 2003 on the effectiveness of teaching and learning English for 5-to 16-year-olds. Eight of the studies provided in depth and high quality reviews of the effectiveness of ICT in the teaching and learning of written composition in English. Three types of ICT intervention were used in the studies stated above - computer assisted instruction or computer-aided learning, word processing and multimedia. The word processing software was mainly used as many of the research studies reviewed above are writings related in nature. ICT was mainly used to improve the learners' proficiency in spelling and grammar. In one of the research studies, the constructive application of multimedia technology was used to improve writing performance. However, the results and outcomes of the research studies were inconclusive.

Melhuish (2008) highlighted the evolving notion of text, context and curriculum vis-àvis the current proliferation of ICT use in educational settings and more specifically with the use of Web 2.0 tools. The social, collaborative nature of Web 2.0 offers English teachers and their students' new opportunities to re-examine how the language could be taught and learnt via such online social platforms. The web effectively helps to develop students' personal voices by providing them with platforms for digital selfexpression. This development is harder to achieve through conventional written assignments. This approach provides a much wider readership with more valid and authentic writer-reader relationships than that between students and teachers.

Mullamaa (2010) shared the experience in using an e-learning environment for the teaching of English. The focus was to support student-centred learning to increase student motivation, individualisation and cooperation in creating students' own learning digital materials. Students were engaged in the building of their own learning materials, such as databases on specific research topics, digital presentations and online dictionaries; and also the more traditional approaches, such as, online selfcorrecting grammar and vocabulary exercises, email and course calendar and other relevant information.

\section{Use of ICT in the teaching of mathematics}

Bosco (2004) observed that there was a change in the interaction pattern between teacher and students with the use of ICT in the teaching of mathematics: the students' focus moved from the teacher to the computer. "...closed programs tended to promote a type of interaction that did not favour the discussion of ideas. In fact, the exchanges produced among the children in the 'drill and practice' classes never went beyond cumulative chats" (Bosco, p. 276). By contrast, the use of open programs promotes learning through construction rather than passive reception.

Crisan, Lerman and Winbourne (2007) highlighted several factors influencing mathematics teachers' integration of ICT into their lessons. Contextual factors such as the school context, departmental ethos and the availability of and accessibility to ICT facilities, key persons promoting the ICT use within the department, teacher ICT skills, ICT professional development and the presence of ICT within the mathematics scheme of work. Interesting in Crisan, Lerman and Winbourne's (2007) findings was how personal teacher factors influenced the use of ICT in the teaching of mathematics. 
Law (2009) found that the most frequently adopted activities by mathematics teachers in her research study were 'exercise to practise skills or procedures', 'teacher lectures' and 'discovering mathematics concepts and principles'. Although Law (2009) reported a change in pedagogical approach by teachers when ICT was being used, the more conventional and traditional pedagogical approaches still prevailed, especially in some countries (e.g., Hong Kong, Singapore and Taiwan). Teachers in the above-mentioned countries were reported to value a more traditionally oriented curriculum, as compared to curriculum goals that focused on lifelong learning and connectedness.

McAlister, Dunn and Quinn (2005) examined teachers' attitudes towards the use of computers in teaching mathematics in the primary school classroom. Positive attitudes of teachers towards the use of ICT in teaching and the availability of the necessary resources would facilitate the use of computers in teaching mathematics in the primary classroom. The computers could be used as a tool in supporting and enhancing students' learning as well as a tool for teaching.

The literature studies reviewed above suggest that the teaching of English and mathematics could adopt various approaches - learning from and with ICT, with or without production and with or without collaboration (Table 1). In addition the literature also further suggests that the integration of ICT into the classroom depends on individual teachers as well as the schools' contextual factors. Teachers' beliefs have been viewed as a key area that needs to be addressed in the context of integration of ICT into classrooms (Gao, Wong, Choy \& Wu, 2010; So \& Kim 2009). Many other studies also reported that teachers' beliefs could affect the integration of ICT into the classroom (Chere-Masopha \& Bennett, 2007; Garthwait \& Weller, 2005; Hayes, 2007; Penuel, 2006; Sipilä, 2010; Tondeur, Cooper \& Newhouse, 2010; Towndrow \& Vaish, 2009). However, it is also important to note that "technology itself is not likely to improve ineffective teaching practices" (Tee \& Lee, 2011, p. 101).

\section{Research design and methods}

\section{Case study research design}

A case study approach is used in this research study to look into how ICT has been integrated into the teaching of English and mathematics in this primary school. More specifically, this research case study examines the pedagogical approaches adopted by the English and mathematics teachers. This study looks into how subject content affects the pedagogy used by the teachers and in this case, the teaching of primary school level English and mathematics with the integration of ICT.

\section{Research methods}

The following research methods were used in the data collection and analysis:

1. Document review. In this case, the documents reviewed were mainly the research reports and conference presentations produced by the teachers involved, on how they had integrated ICT into their teaching. Lesson plans were also reviewed.

2. Interviews with teachers. A total of 10 teachers, 5 English and 5 mathematics teachers, taught the seven Primary 4 classes. Of the 10 teachers, 5 English and 3 mathematics teachers were interviewed. Two of the mathematics teachers were unavailable for 
interview as one was on leave and the other joined another school at the time of this study. More detailed information about the teachers who were interviewed is given in Table 2 below. Four of the teachers taught two English and two mathematics classes as shown in Table 2. All the teachers were interviewed individually so that the responses from the teachers could be independent of and uninfluenced by one another. These sessions took the form of informal interviews; basically in the form of semi-casual chitchat sessions based on how they had integrated ICT into their lessons. All the interview sessions were audio recorded in May 2011 and transcribed for analysis.

Table 2: Teachers who taught Grade 4 English and mathematics and the number of years of experience

\begin{tabular}{|c|c|c|c|c|}
\hline Class & $\begin{array}{l}\text { English } \\
\text { teacher }\end{array}$ & $\begin{array}{l}\text { No. of years } \\
\text { of experience }\end{array}$ & $\begin{array}{c}\text { Mathematics } \\
\text { teacher }\end{array}$ & $\begin{array}{l}\text { No. of years } \\
\text { of experience }\end{array}$ \\
\hline 1 & Teacher A\# & 6 & Teacher $\mathrm{V}^{*}$ & 20 \\
\hline 2 & Teacher B & 7 & Teacher W\# & 18 \\
\hline 3 & Teacher C\# & 9 & Teacher X & 8 \\
\hline 4 & Teacher D & 8 & Teacher $\mathrm{Y} \# \wedge^{\wedge}$ & 20 \\
\hline 5 & Teacher F & 10 & Teacher Z & 9 \\
\hline 6 & Teacher A\# & 6 & Teacher $\mathrm{Y} \# \wedge$ & 20 \\
\hline 7 & Teacher C\# & 9 & Teacher W\# & 18 \\
\hline \multicolumn{5}{|c|}{$\begin{array}{l}\text { * Unable to interview Teacher V as she was on leave due to family commitments. } \\
\text { ^ Unable to interview Teacher Y, who was posted out when the research was } \\
\text { conducted. } \\
\text { \# Denotes the same teacher teaching two different classes of the same subject. For } \\
\text { instance, Teacher A taught both Class } 1 \text { and } 6 \text { for English. }\end{array}$} \\
\hline
\end{tabular}

3. Group interviews with students. In addition, a total of 28 students ( 4 from each of the seven classes) were interviewed also. Group interviews were conducted for the students by the class they were in and there were 4 students in each group. The group interviews were conducted to obtain their perspectives and as a source for triangulation. The interview questions focused on how English and mathematics lessons were conducted for them, and how ICT was used in those lessons. All the interview sessions were audio recorded in May 2011 and transcribed for analysis.

4. Student self-reported questionnaire. A self-reported questionnaire survey was administered to all the 225 students who were involved in the student computer ownership program and the school one-to-one computing program, to ascertain the frequency of ICT usage in their English and mathematics classes. A total of 216 students responded to the online questionnaire survey. The students were also asked how they felt with regard to the use of ICT for the learning of English and mathematics. The self-reported questionnaire survey included the following questions: the frequency of ICT usage, online games and applets, learning management system, blogs and online social networking software use, in both English and mathematics lessons. The questions were adapted from Samuelsson (2010). The frequency of use is based on a Likert scale of 1 to 7 ( 1 = once a month, 2 = once every 3 weeks, 3 = once every 2 weeks, $4=$ once every 10 days, $5=$ once every week, 6 = once every 2 to 3 days and 7 = once every day). 


\section{Key findings}

\section{How ICT was integrated in the teaching of English and mathematics}

\section{Online quizzes - learning from ICT (predominantly transmissive, without production and} without collaboration)

The online quiz module found in the online management system of the school was a feature used by both English and mathematics teachers to facilitate students' learning of the subjects. From observations and interviews with teachers and students, the selfmarking function in the quiz module reduced marking time for teachers and also provided the teacher with a quick and accurate overview of the students' understanding of the basic content knowledge taught. In addition, students were also given instantaneous feedback on their responses. The teachers also observed that students were more motivated to attempt the questions repeatedly in order to get the correct answer. Hence, the use of ICT can allow students to reinforce their learning through repeated exercises.

The teachers also reflected that the readily available item analysis made it easier for the teachers to take follow up actions to address any misconceptions. Students learn from ICT through their attempts in online quizzes to practise and reinforce the content knowledge that they have learned. The online quizzes provided for a more transmissive pedagogical approach, without much degree of production and collaboration. Both teachers and students reflected that the online quizzes were more frequently used in mathematics lessons as compared to English lessons. Mathematics teachers reflected that the quiz approach taken was due to the nature of the subject whereby students needed good basics in the procedural skills, and conceptual knowledge to work out the correct answers. The English teachers also shared that they selected the use of the quiz module to reinforce some of the grammar items taught in class.

\section{Online dissemination of information and digital learning materials - learning from ICT}

(mainly transmissive, without production and collaboration)

Both the English and mathematics teachers set up blog sites for the dissemination of online teaching and learning information and resources. Through the interviews with the teachers and students, we found that mathematics teachers used this approach in their teaching more frequently when compared to the English teachers. For instance, one of the mathematics teachers created and maintained the blog sites weekly for the various levels, with Internet links to the relevant teaching online resources, games and manipulatives. These blogs allowed students to access suitable educational online games and manipulatives that were related to what was taught in class. The teachers also used some of the free and readily available online manipulatives to make their lessons more interesting and engaging. This is another instance of learning from ICT with the transmission of learning content via the online platforms. Figure 1 shows a sample mathematics blog site with the consolidated links to the quizzes and online digital manipulatives for easy access by students to learn from the ICT and for more independent learning.

Online journal, reflections on learning, computer programming and spreadsheets - learning with ICT (constructionist and dialogic, with production and collaboration)

Several English teachers encouraged their students to post their reflections and thoughts as online journals via online blog sites. The teachers saw the potential in 
using these ICT tools to enhance students' acquisition of English language skills. The teachers modelled the writing and steps on how to post their journal online. The students' online journals were commented upon by both the English teacher and their classmates. This process encouraged the students to express themselves more clearly as they needed to be understood, especially by their peers. The students were also observed to write more frequently through their blogs. The students were engaged in constructing and producing their own online journals; they were also engaged in online dialogue and exchanges through the comments posted via the blogs. This is an instance of learning with ICT - production and collaboration - with students writing their personal journals and receiving comments from their peers/classmates and teacher.

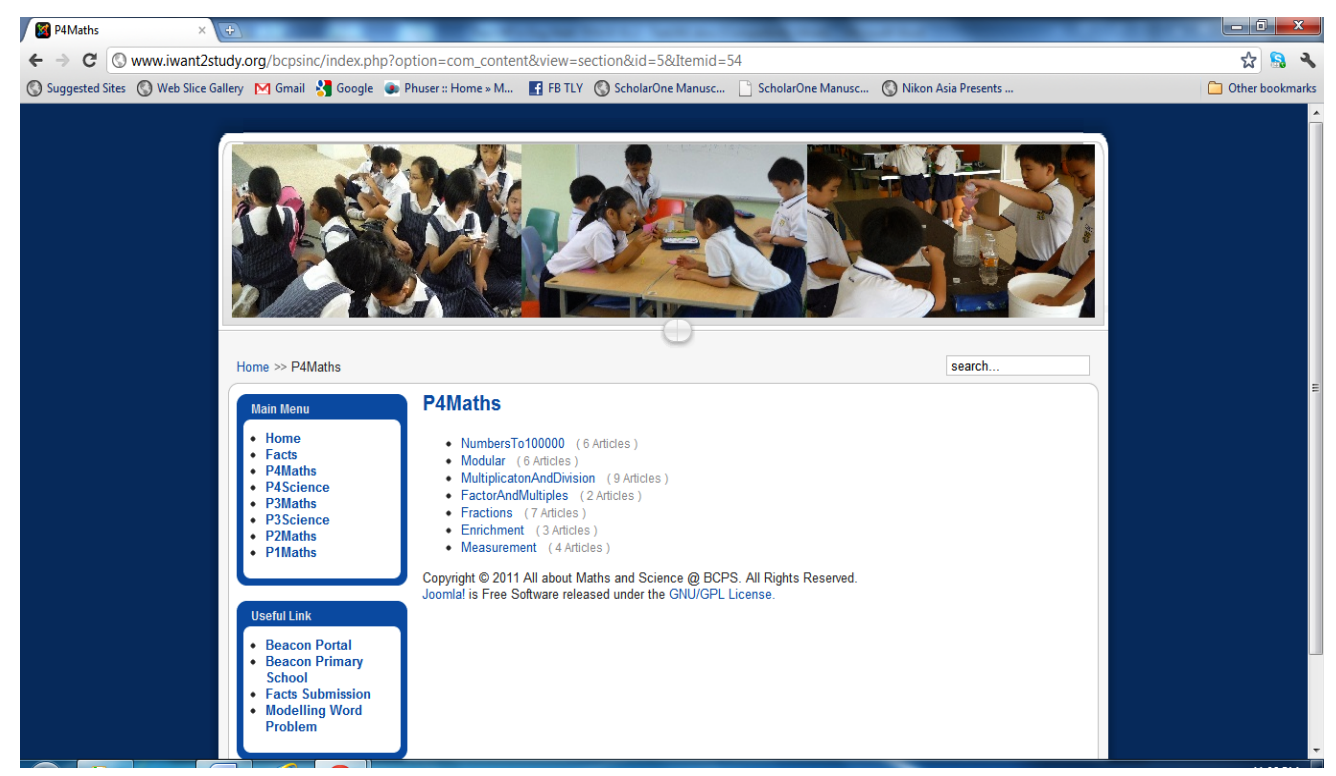

Figure 1: Screen capture of a mathematics blog site

One of the mathematics teachers taught her students computer programming using the program Scratch, an intuitive graphical computer programming language developed by Massachusetts Institute of Technology for young children. She analysed her students' Scratch projects and also interviewed and surveyed them. Her exploration provided encouraging evidence that computer programming had the potential to equip the young children with digital literacy and problem solving skills. This is one example of learning with ICT through a constructionist pedagogical approach.

All students from the various Primary 4 classes were also exposed to the creation of pictorial graphs using a spreadsheet software application to analyse trends and patterns. This is another example of teachers believing in learning with ICT based on a constructionist perspective.

Digital story telling - learning with ICT (constructionist and co-constructionist, with production and collaboration)

The English teachers engaged the students in the creation of their digital stories, a key pedagogical approach used by the school for the learning of languages and media 
literacy skills. The lesson idea was very simple. The students used an appropriate software application to create a digital story with text, digital images and sound recordings (i.e., students' own voices in narrating their stories). Pupils were given a series of scaffolding tasks prior to the completion of their digital story telling assignments, which included brainstorming for ideas in groups or pairs for profiles of characters, drafting of story outlines and finally recording their narration of the stories. Subsequently, teachers provided feedback for improvement when pupils have completed the various tasks at different times.

The completed digital stories were then published in the school network and the Internet, via blog sites, so that peers and parents could view and also provide their comments and words of encouragement. This process of transforming the students' ideas into text enhanced by the use colourful visuals and music, excited and engaged them. Facilitated by ICT to present their digital stories, students could easily create and refine their stories and learn from each other in the creation process. In recording the narration of their stories, students attempted multiple readings and recordings till they felt satisfied with their digital readings. This is an instance where English teachers facilitated students to learn with ICT - production and collaboration; the students created and also co-created their digital stories.

\section{Frequencies of ICT use in English and mathematics lessons}

All students from the Primary 4 level classes participated in an online questionnaire survey on their frequency of usage for: (1) ICT, (2) learning management system, (3) blogs, (4) online games and applets, and (5) online social networking tools (e.g., chats, MSN and forum) in school for the learning of English and mathematics. The frequency of use is based on a Likert-scale of 1 to 7 as stated above. The details of the mean frequencies are reported in Table 3. There were significant differences in the frequency of ICT use for English and mathematics, and frequency of the use of online games and applets for the learning of English and mathematics. The $t$-tests statistics were $t(409)=$ $3.569, p<0.001$ and $t(424)=2.678, p<0.05$, respectively. The frequencies of the use of the learning management system, blogs and online social networking tools are also reported in Table 3. However, there were no significant differences in the use of the learning management system, blogs and online social networking tools between the learning of English and mathematics. The $t$-tests statistics were $t(419)=0.707, p>0.05$, $t(422)=1.090, p>0.05$ and $t(429)=1.452, p>0.05$, respectively.

Table 3: Frequency of use of ICT, online games/applets, learning management system, blogs, and online social networking software

\begin{tabular}{|l|l|c|c|c|c|}
\hline & \multicolumn{1}{|c|}{ Subject } & $\mathrm{N}$ & Mean & Std dev & $t$-tests \\
\hline \multirow{2}{*}{ Frequency of ICT use } & English & 216 & 5.16 & 1.750 & $t=3.569$ \\
& Mathematics & 214 & 4.48 & 2.155 & $p<0.05^{*}$ \\
\hline $\begin{array}{l}\text { Frequency of online games and } \\
\text { applets use }\end{array}$ & English & 215 & 3.99 & 2.129 & $t=2.678$ \\
\cline { 2 - 5 } $\begin{array}{l}\text { Frequency of learning management } \\
\text { system use }\end{array}$ & Mathematics & 215 & 4.52 & 1.936 & $p<0.05^{*}$ \\
\hline Frequency of blog use & English & 209 & 3.89 & 2.185 & $t=0.707$ \\
\cline { 2 - 5 } & Mathematics & 212 & 4.03 & 2.105 & $p>0.05$ \\
\hline Frequency of online social networking & English & 210 & 4.46 & 2.082 & $t=1.090$ \\
\cline { 2 - 5 } & Mathematics & 214 & 4.24 & 2.052 & $p>0.05$ \\
\hline use (e.g., email, MSN, forum, chat) & English & 215 & 4.15 & 2.175 & $t=1.452$ \\
\cline { 2 - 5 } & Mathematics & 216 & 3.85 & 2.206 & $p>0.05$ \\
\hline
\end{tabular}


A one-way ANOVA was used to test for differences in the frequency of ICT use in the seven English language classes. The seven classes were similar in academic performance. The frequency of ICT use in the English language classes differed significantly across the seven classes, $F(6,209)=10.233, p<0.005$. Tukey post-hoc comparisons of the seven classes revealed that Class $3(M=5.72,95 \%$ CI $[5.11,6.33])$ indicated significantly higher frequency of ICT usage rate than Class $2(M=4.39,95 \%$ CI $[3.73,5.05])$. Class 4 also $(M=5.93,95 \%$ CI $[5.34,6.53])$ reported significantly higher ICT usage rate than Class $1(M=4.56,95 \%$ CI $[3.88,5.24])$ and Class $2(M=4.39,95 \%$ CI $[3.73,5.05])$. The detailed mean frequencies of ICT use are shown in Table 4.

Table 4: Frequency of ICT use in various English language classes

\begin{tabular}{|c|c|c|c|c|c|c|}
\hline \multirow{2}{*}{ Class } & \multirow{2}{*}{$\mathrm{N}$} & \multirow{2}{*}{ Mean } & \multirow{2}{*}{ Std. dev. } & \multirow{2}{*}{ Std. error } & \multicolumn{2}{|c|}{ 95\% confidence interval for mean } \\
\cline { 6 - 7 } & & & & & Lower bound & Upper bound \\
\hline 1 & 32 & 4.56 & 1.883 & .333 & 3.88 & 5.24 \\
\hline 2 & 31 & 4.39 & 1.801 & .324 & 3.73 & 5.05 \\
\hline 3 & 32 & 5.72 & 1.689 & .299 & 5.11 & 6.33 \\
\hline 4 & 30 & 5.93 & 1.596 & .291 & 5.34 & 6.53 \\
\hline 5 & 28 & 5.46 & 1.710 & .323 & 4.80 & 6.13 \\
\hline 6 & 31 & 5.00 & 1.549 & .278 & 4.43 & 5.57 \\
\hline 7 & 32 & 5.09 & 1.573 & .278 & 4.53 & 5.66 \\
\hline Total & 216 & 5.16 & 1.750 & .119 & 4.92 & 5.39 \\
\hline
\end{tabular}

Similarly, a one-way ANOVA was used to test for differences in the frequency of ICT use in the seven mathematics classes. The seven classes were similar in academic performance. The frequency of ICT use in the mathematics classes differed significantly across the seven classes, $F(6,207)=8.102, p<0.001$. Tukey post-hoc comparisons of the seven classes indicated that Class $1(M=5.72,95 \%$ CI $[5.19,6.25])$ reported significantly higher frequency of ICT usage in class as compared to Class $4(M$ $=3.9,95 \%$ CI $[3.05,4.75])$, Class $5(M=3.39,95 \%$ CI $[2.46,4.33])$, Class $6(M=4.16,95 \%$ CI $[3.43,4.90])$ and Class $7(M=3.55,95 \%$ CI $[2.90,4.20])$. Similar to Class 1 , Class $3(M$ $=5.94,95 \%$ CI $[5.26,6.61])$ also reported significantly higher frequency of ICT usage as compared to Class $4(M=3.9,95 \%$ CI $[3.05,4.75])$, Class $5(M=3.39,95 \%$ CI [2.46, 4.33]), Class $6(M=4.16,95 \%$ CI $[3.43,4.90])$ and Class $7(M=3.55,95 \%$ CI $[2.90,4.20])$. The detailed mean frequencies of use are shown in Table 5.

Table 5: Frequency of ICT use in various mathematics classes

\begin{tabular}{|c|c|c|c|c|c|c|}
\hline \multirow{2}{*}{ Class } & \multirow{2}{*}{$\mathrm{N}$} & \multirow{2}{*}{ Mean } & \multirow{2}{*}{ Std. dev. } & \multirow{2}{*}{ Std. error } & \multicolumn{2}{|c|}{ 95\% confidence interval for mean } \\
\cline { 5 - 7 } & & & & & Lower bound & Upper bound \\
\hline 1 & 32 & 5.72 & 1.464 & .259 & 5.19 & 6.25 \\
\hline 2 & 31 & 4.55 & 1.929 & .347 & 3.84 & 5.26 \\
\hline 3 & 31 & 5.94 & 1.843 & .331 & 5.26 & 4.75 \\
\hline 4 & 30 & 3.90 & 2.280 & .416 & 3.05 & 4.33 \\
\hline 5 & 28 & 3.39 & 2.409 & .455 & 2.46 & 4.90 \\
\hline 6 & 31 & 4.16 & 2.002 & .360 & 3.43 & 4.20 \\
\hline 7 & 31 & 3.55 & 1.767 & .317 & 2.90 & 4.77 \\
\hline Total & 214 & 4.48 & 2.155 & .147 & 4.19 & \\
\hline
\end{tabular}

\section{Discussion and implications}

In response to the research questions stated in the introduction section, our findings suggested that the teachers used a variety of approaches to integrate ICT into the teaching of English and mathematics. 
From the survey data, no significant differences were found in the usage rates of learning management system, blogs and online social networking applications by the students in English and mathematics classes. The mathematics teachers adopted a more learning from ICT perspective and approach as compared to the English teachers. Students reported less ICT usage frequency in mathematics classes than English classes. However, students used online games and applets more often in their learning of mathematics than English. All the mathematics teachers shared that due to the nature of the subject and how the students are assessed, constant practice is required for them to clear or do well in the assessments. Reinforcement of basic computational and arithmetic skills require more 'drill and practice' type of pedagogy through the use of quizzes found within the learning management system and the 'playing' of (or the learning from) the online mathematics educational games. This allowed the pupils to learn basic concepts more independently and obtain instantaneous feedback. When presented with the data in general, mathematics teachers were not surprised that the usage rate of ICT fell short as compared to the usage during English lessons, as there were also paper and pencil worksheets for the more open-ended problem sums to be completed.

However, there were snippets of learning with ICT in the learning of mathematics, where students were taught computer programming and also the creation of pictorial graphs using spreadsheet software. In general, the teaching of mathematics took a more learning from ICT and transmissive pedagogical approach with fewer occasions for learning with ICT, dialogic, constructionist and co-constructionist approaches. In this instance, the proposed framework provided a useful conceptual framework in highlighting the less frequent use of learning with computers. Teachers could then be more aware and conscious to design mathematics lessons that could facilitate the learning with ICT, based on a more dialogic, constructionist and co-constructionist approach.

The English teachers seemed to use a wider variety of pedagogical approaches, as compared to the mathematics teachers, in their lessons. Both learning from and learning with technology approaches were used. Elements of transmissive, dialogic, constructionist and co-constructionist approaches were present. Teachers made use of online social networking applications to transmit information, learning resources, online quizzes, and also to allow students to comment on one another's journal writing and other digital products. Students were also given opportunities to construct or write their own digital stories or compositions with their personal voices embedded in both offline and online software applications. Online software applications also provided avenues for collaboration with peers and teachers. However, the element of co-construction was less evident in the findings.

Another interesting observation from the findings was the difference in the frequency of ICT use among the different classes in the same subject. There were seven classes at Primary 4 level and these were taught by five different teachers. The ANOVA analysis for the frequency of ICT use in the various English and mathematics classes revealed that there were significant differences. The classes were situated in the same school with identical technological infrastructure, curriculum and assessment modes. The main factor that could have caused this difference in the ICT usage rate by the students would be the teacher. For instance and coincidentally, the mathematics teacher who set up the blog sites and quizzes in the learning management system was the same teacher who taught Class 3, which was reported to have the highest frequency of ICT use 
among all. The mathematics teacher commented that she provided "buffet style resources that were mainly web resources and digitised diagnostic tests for optional use. Subject teachers will use these materials at their own discretion and decide what is best for the class. Resources are already there".

Crisan, Lerman and Winbourne (2007) also highlighted that differences in ICT use could be due to teacher personal factors. "...teachers' conceptions of ICT affected their incorporation of ICT" (Crisan, Lerman \& Winbourne, 2007, p. 31). Similarly, Class 4, which recorded the highest ICT usage rate, had an English teacher who spoke passionately about the various uses of online social networking software applications for students to post their journals and exchanges. These findings highlighted the importance of the teacher in the use and integration of ICT in teaching and learning, which is also congruent to the findings from Crisan, Lerman and Winbourne (2007), where teachers' personal ICT conceptions affected how they used ICT in their teaching. Teachers' belief in the potential of ICT was an important factor that contributed to the high frequencies of ICT usage in Class 3 mathematics and Class 4 English. Through the interview with both teachers who taught the above-mentioned two classes, they reflected that ICT engaged their students and helped students to learn better, and even if ICT could not increase their students' academic performance, students would still acquire 21st century competencies such as information and media literacy.

There was no significant difference in the frequencies of ICT use for both English and mathematics for the other four teachers who taught two classes of either English or Mathematics. This further suggested that the difference in the frequency of ICT use was teacher dependent and not class or student dependent.

\section{Conclusion}

The learning from and learning with ICT perspective as proposed by Ringstaff and Kelly (Kelley) (2002) provided a good conceptual framework on how ICT could be used and integrated. Bower, Hedberg and Kuswara (2010) further extended it to include the production and collaborative dimensions. These concepts and perspectives of learning from and with ICT, with or without production and with or without collaboration could be used to extend educational technology framework and theory. In addition, this study also suggested the pivotal role played by the teacher in the use and integration of ICT for learning.

This research case study also illuminated the usefulness of the proposed frameworks and the perspectives that it could provide researchers and teachers alike. More specifically, this case study highlighted the interaction between how content (i.e., English and mathematics) influences pedagogy, and vice versa when ICT was included. This has provided useful knowledge about and better understanding of the technological, pedagogical and content (TPACK) framework as proposed by Mishra and Koehler (2006).

\section{Acknowledgments}

The authors would like to thank the participants for making this study possible. We also wish to thank $\mathrm{Mr} \mathrm{Ng}$ Jinsheng (BSc, MSc), a statistician and data miner, who has assisted and advised on the quantitative analysis. 


\section{References}

Abas, S., Fong, Y. K., Yu, S. H. S. \& Lee, C. B. (2010). A case study of how digital storytelling was used in a lower primary English classroom. In L.Y. Tay, C. P. Lim \& M. S. Khine (Eds.), A school's journey into the future: Research by practitioners for practitioners (pp.89-109). Singapore: Pearson.

Andrews, R., Freeman, A., Hou, D., McGuinn, N., Robinson, A. \& Zhu, J. (2007). The effectiveness of information and communication technology on the learning of written English for 5- to 16-year-olds. British Journal of Educational Technology, 38(2), 325-336. http: / / dx.doi.org/10.1111/j.1467-8535.2006.00628.x

Bosco, A. (2004). ICT resources in the teaching of mathematics: Between computer and school technologies. A case-study. The Curriculum Journal, 15(3), 265-280. http: / / dx.doi.org/10.1080/09585170412331311510

Bower, M., Hedberg, J. \& Kuswara, A. (2010). A framework for Web 2.0 learning design. Educational Media International, 47(3), 177-198. http: / / dx.doi.org/ 10.1080/09523987.2010.518811

Chere-Masopha, J. C. \& Bennett, S. (2007). Using teacher professional identity to understand classroom ICT practices. The International Journal of Learning, 14(7),75-82. http: / / ijl.cgpublisher.com/product/pub.30/prod.1457

Crisan, C., Lerman, S. \& Winbourne, P. (2007). Mathematics and ICT: A framework for conceptualising secondary school mathematics teachers' classroom practices. Technology, Pedagogy and Education, 16(1), 21-39. http: / / dx.doi.org/ 10.1080/14759390601167991

Fontana, A. \& Frey, J. H. (1994). Interviewing: The art of science. In N. K. Denzin \& Y. S. Lincoln (Eds.), Handbook of qualitative research (pp. 361-376). Thousand Oaks, California: SAGE Publications, Inc.

Gao, P., Wong, A. F. L., Choy, D. \& Wu. J. (2010). Developing leadership potential for technology integration: Perspectives of three beginning teachers. Australasian Journal of Educational Technology, 26(5), 643-658. http:/ / www.ascilite.org.au/ajet/ajet26/gao.html

Garthwait, A. \& Weller, H.G. (2005). A year in the life: Two seventh grade teachers implement one-to-one computing. Journal of Research on Technology in Education, 37(4), 361-375. http: / / www.eric.ed.gov/ PDFS /EJ690978.pdf

Gillham, B. (2000). Case study research methods. New York: Continuum.

Jonassen, D. H. (2000). Computers as mindtools for schools: Engaging critical thinking (2nd Ed.). Upper Saddle River, New Jersey: Merrill/Prentice Hall.

Harris, A. L. \& Rea, A. (2009). Web 2.0 and virtual world technologies: A growing impact on IS education. Journal of Information Systems Education, 20(2), 137-144.

Hayes, D. (2007). ICT and learning: lessons from Australian classrooms. Computers E Education, 49(2), 385-395. http: / / dx.doi.org/10.1016/j.compedu.2005.09.003

Law, N. (2009). Mathematics and science teachers' pedagogical orientations and their use of ICT in teaching. Education and Information Technologies, 14(4), 309-323. http: / / dx.doi.org/ 10.1007/s10639-009-9094-z 
Lim, C. P. \& Tay, L. Y. (2003). Information and communication technologies (ICT) in an elementary school: Engagement in higher order thinking. Journal of Educational Multimedia and Hypermedia, 12(4), 425-451. http:/ / www.editlib.org/p/11931

Melhuish, K. (2008). 2.0 be or not 2.0 be: How English teachers are embracing the world wide web. English in Aotearoa, 27(1), 23-30.

Merriam, S. B. (1998). Qualitative research and case study applications in education. San Francisco: Jossey-Bass Publishers.

McAlister, M., Dunn, J. \& Quinn, L. (2005). Student teachers' attitudes to and use of computers to teach mathematics in the primary classroom. Technology, Pedagogy and Education, 14(1), 77105. http:/ / dx.doi.org/10.1080/14759390500200194

Mishra, P. \& Koehler, M. J. (2006). Technological pedagogical content knowledge: A new framework for teacher knowledge. Teachers College Record, 108(6), 1017-1054. http: / / punya.educ.msu.edu/publications / journal_articles / mishra-koehler-tcr2006.pdf

Mullamaa, K. (2010). ICT in language learning - benefits and methodological implications. International Education Studies, 3(1), 38-44.

http: / / ccsenet.org/journal/ index.php/ies/article/ download / 4965/4131

Penuel, W. R. (2006). Implementation and effects of one-to-one computing initiatives: A research synthesis. Journal of Research on Technology in Education, 38(3), 329-348. http: / / www.eric.ed.gov/PDFS/EJ728908.pdf

Ringstaff, C. \& Kelley, L. (2002). The learning return on our educational technology investment: A review of findings from research. San Francisco: WestEd.

http:/ / www.wested.org/online_pubs/learning_return.pdf

Samuelsson, U. (2010). ICT use among 13-year-old Swedish children. Learning, Media and Technology, 35(1), 15-30. http:/ / dx.doi.org/10.1080/17439880903560936

Sipilä, K. (2010). The impact of laptop provision on teacher attitudes towards ICT. Technology, Pedagogy and Education, 19(1), 3-16. http: / / dx.doi.org/10.1080/14759390903579257

So, H.-J. \& Kim, B. (2009). Learning about problem based learning: Student teachers integrating technology, pedagogy and content knowledge. Australasian Journal of Educational Technology, 25(1), 101-116. http: / / www.ascilite.org.au/ajet/ajet25/ so.html

Stake, R. (1995). The art of case study research. Thousand Oaks, California: SAGE Publications, Inc.

Stewart, D. W. \& Shamdasani, P. N. (1997). Focus group research: exploration and discovery. In L. Bickman \& D. J. Rog (Eds.), Handbook of applied social research methods (pp. 505-526). Thousand Oaks, California: SAGE Publications, Inc.

Tay, L. Y., Nair, S. \& Lim, C. P. (2010). Supporting one-to-one computer-mediated learning environments in a Singapore primary school. In L. Y. Tay, C. P. Lim \& M. S. Khine (Eds.), A school's journey into the future: Research by practitioners for practitioners (pp.39-67). Singapore: Pearson.

Tee, M. Y. \& Lee, S. S. (2011). From socialisation to internalisation: Cultivating technological pedagogical content knowledge through problem-based learning. Australasian Journal of Educational Technology, 27(1), 89-104. http:/ / www.ascilite.org.au/ajet/ajet27/ tee.html 
Tondeur, J., Cooper, M. \& Newhouse, C. P. (2010). From ICT coordination to ICT integration: A longitudinal case. Journal of Computer Assisted Learning, 26(4), 296-306.

http: / / dx.doi.org/10.1111/j.1365-2729.2010.00351.x

Towndrow, P. A. \& Vaish, V. (2009). Wireless laptops in English classrooms: A SWOT analysis from Singapore. Educational Media International, 46(3), 207-221.

http: / / dx.doi.org/ 10.1080/ 09523980903135335

Yin, R. K. (1994). Case study research: Design and methods (2nd Ed.). Thousand Oaks, California: SAGE Publications, Inc.

Young, A. C. (1997). Higher-order learning and thinking: What is it and how is it taught? Educational Technology, 37(4), 38-41.

Authors: Lee-Yong Tay PhD, Head of Research \& ICT

Beacon Primary School, Singapore

FutureSchools@Singapore

36 Bukit Panjang Ring Road, Singapore 679944

Email: tay_lee_yong@moe.edu.sg

Siew-Khiaw Lim $M A, M S c$, Vice-Principal

Beacon Primary School, Singapore. Email: lim_siew_khiaw@moe.gov.sg

Professor Cher-Ping Lim PhD, Department of Curriculum and Instruction Head of Outcome-Based Learning, Centre for Learning, Teaching and Technology Hong Kong Institute of Education, China. Email: clim@ied.edu.hk

Hwee-Ling Joyce Koh $\mathrm{PhD}$, Assistant Professor

Learning Sciences and Technology Group

National Institute of Education, Nanyang Technological University, Singapore Email: joyce.koh@nie.edu.sg

Please cite as: Tay, L. Y., Lim, S. K., Lim, C. P. \& Koh, J. H. L. (2012). Pedagogical approaches for ICT integration into primary school English and mathematics: A Singapore case study. Australasian Journal of Educational Technology, 28(4), 740-754. http: / / www.ascilite.org.au/ajet/ajet28/tay.html 